2021 Vol. 4

Original-, Udviklings- og kvalitetssikringsartikler

Fie Brosbøl Kobberup RN, MSc in Innovation in Health

Care, Copenhagen Business School

Brit-Silje Sode

$R N, M S c$ in Innovation in Health

Care, Copenhagen Business School

Gitte Boier Tygesen

Ph.D., MHSc, RN, Emergency

Department, Aarhus University

Hospital.

Malik Kalmriz

Ph.D., Læge, Emergency

Department, Horsens Regional

Hospital, Denmark

Nøgleord

Electronic patient records

Medical history taking/methods

Patient-generated health data

Patient involvement

Kontaktinformation e-mail: fie.brosboel@gmail.com

\section{Investigating the possibilities of using patient-generated health data in emergency care: an explorative study Resume}

Background: It is well known that emergency departments (EDs) are exposed to human errors and unintended events due to large patient flow, high work pressure and overload of information. Strategies for providing efficient and effective health care are therefore imperative, and health information technologies are suggested to be one of the solutions. This study sought to investigate if the use of patientgenerated health data gathered through a digital patient questionnaire and visualised as a patient-generated journal (PGJ v.1.0) has the potential to improve the care delivered in EDs.

Methods: Using a mixed-method approach, the PGJ (v.1.0) was investigatedfrom key stakeholders' perspectives. First, we examined the PGJ from a patient perspective via participant observation $(n=18)$ and interviews $(n=18)$, supported by statistical data from the PGJ $(n=56)$. Second, we used questionnaires to explore the physicians' perspectives $(n=9)$. Lastly, two interviews were conducted with healthcare leaders from the ED. The data were compared and analysed using descriptive statistics and hermeneutic analysis.

Results: From the findings, it appears that patients in need of urgent care accept the use of patient-generated data, and patients highly favoured being active in their patient pathway. However, the system needed some adjustments to fit the patients'abilities in urgent situations. The physicians expressed mixed attitudes towards the PGJ: the majority agreed that the system needed some adjustments in order for the full benefits to be gained, but thought that it had potential to improve their work processes when fully developed.

Conclusions: This study concludes that the use of patient-generated data is well accepted by patients in an urgent setting, and that the PGJ has the potential to improve quality of care in patient pathways by adding value to patient flows as well as clinical workflows. The concept of utilising patient-generated health data in emergency care should therefore be further developed and investigated.

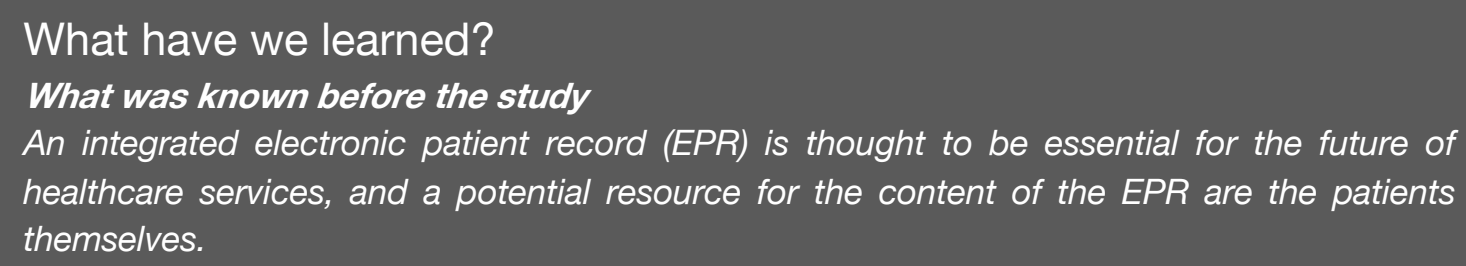

\title{
Perspectives
}

This article can inspire further development of the concept of utilising patient-reported data in an urgent setting. 


\section{Introduction}

It is well known and documented in medical scientific studies that emergency departments (EDs) are more exposed to human errors and unintended events than other health departments. Several reasons can help explain this: large patient flow, high work pressure and overload of information (1).

To mitigate some of these challenges, triage procedures have been implemented in EDs. In Denmark, the Danish Emergency Process Triage is most widely used, and has become an integrated part of hospitals' health-information systems, enabling faster documentation and initiation of treatment. Despite this, patients in Denmark still experience waiting time and misdiagnosis (2). Several studies have shown positive results when involving patients in the treatment process using health-information technologies that collect health data through computerised patient questionnaires. Such systems have been proven to capture more relevant information than traditional methods, and also have the added benefit of freeing up time for physicians and other healthcare professionals (HCPs) to perform other tasks (3-7). This study explores the use of a digital patient questionnaire in an emergency setting to gain insights into if and how the system adds

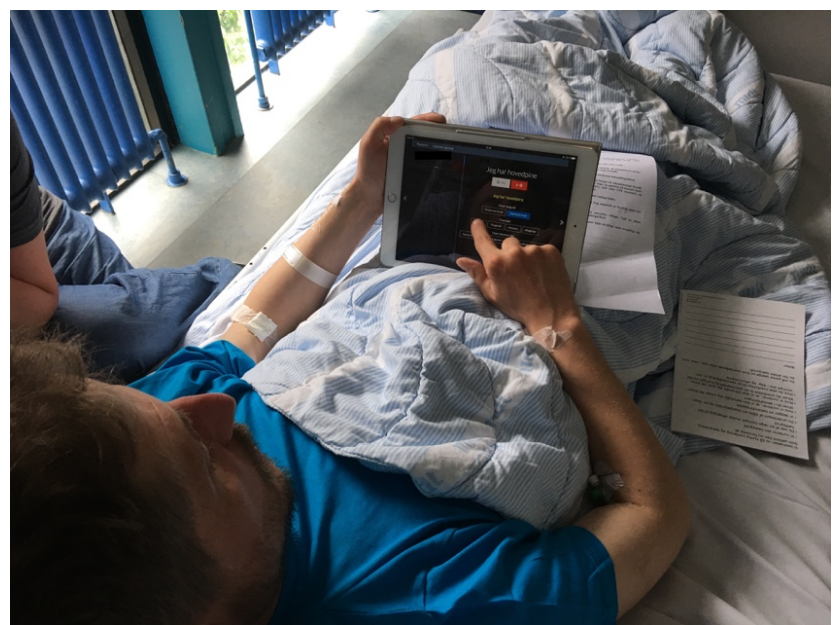

Picture 1: A patient entering data into the PGJ at the ED perceived value for patients and HCPs in diagnostics and treatment processes. The interactive computer system tested in this study is the patient-generated journal (PGJ v.1.0).

\section{Methods}

\section{Design}

The present explorative study was conducted as a part of a master's thesis. It was conducted in the ED at Horsens Regional Hospital (HRH), Denmark, in May 2019, and utilised a mixed-method approach to investigate the PGJ from the perspectives of key stakeholders. The PGJ is an interactive web application that gathers and structures patient health data in a uniformed text format and graphics to aid HCPs and patients in the ED. An illustration of the PGJ data and how it is presented can be seen in Appendix 1.

First, we examined the PGJ from a patient perspective using participant observation and interviews. Data were collected prospectively for one week during day hours at the ED, and 18 patients (Table 1) who were presented to the PGJ upon arrival were included. The patients were purposely chosen for their variance in age, gender, patient type and triage level to ensure a representative sample. As a supplement, statistical data describing the number of symptoms reported and time taken for data entry were extracted retrospectively from 56 PGJs (Table 1). The study included adult patients ( $>18$ years of age) that were evaluated as clinically stable by the HCP's and the DEPT Triage system (e.g. patients with triage category red were excluded). Patients arriving at the ED with an ambulance were included in the study if evaluated as clinically stable. Ineligible patients and patients incapable of entering data into the PGJ were excluded. 
Second, via a questionnaire, we examined if and how the PGJ created perceived value for physicians. Data were collected prospectively for one week, and nine physicians were included (response rate $82 \%$; Table 1). Lastly, two interviews were conducted with healthcare leaders from the ED (Table 1) to gain insights into the possibilities and challenges of using patient-generated data in emergency care.

The collected data were mainly analysed using a hermeneutic approach. For the statistical data, frequencies and means were calculated, and graphs were created to visualise the distribution. Additionally, standard deviations (SD) were calculated for the statistical data extracted from the PGJ.

\section{Ethics}

The study was conducted in collaboration between the ED at HRH and Copenhagen Business School, Denmark. Approvals were obtained from Central
Denmark Region (1-16-02-793-17), and written and oral consent were obtained from eligible patients.

\section{Results}

The majority of patients were positive in their assessment of the PGJ. Patients expressed that the system was easy to use (94.4\%), that it made sense for them to use it while waiting (94.5\%), and that they found it meaningful to report information that the physician could use when assessing them (94.4\%). Some patients (66.7\%) also agreed that the PGJ gave them an improved overview of their condition which benefited the consultation with the physician (Figure 1). The patients expanded their ratings by describing the PGJ as a tool that gave them comfort, helped physicians to become more prepared and targeted in the consultations, and improved patient involvement. However, they also stated that the data entry was too extensive for their abilities and the urgent setting, and that some questions were difficult to understand due to lack of proper framing and delimitation. This was also evident from the observations, where $94.4 \%$ of patients needed support during data entry. Similar

\begin{tabular}{|c|c|c|c|}
\hline & Type of data & Respondents & Characteristics respondents \\
\hline 1 & $\begin{array}{l}\text { Participant } \\
\text { observation and } \\
\text { interviews }\end{array}$ & $\begin{array}{l}18 \text { clinically stable } \\
\text { adult patients }(>18 \\
\text { years of age }) \\
\text { receiving care at the } \\
\text { ED at HRH in May } \\
2019\end{array}$ & $\begin{array}{l}\text { - } \quad \text { Gender: } 9 / 18(50 \%) \text { females, } 9 / 18(50 \%) \text { males } \\
\text { - } \quad \text { Age: range from } 18-76 \text { years, mean age of } 53.7 \text { years } \\
\text { - Triage level (DEPT): } 1 / 18(5 \%) \text { green level, } 14 / 18(78 \%) \text { yellow level, } 3 / 18(17 \%) \text { orange } \\
\text { level }\end{array}$ \\
\hline 2 & $\begin{array}{l}\text { Statistical data } \\
\text { extracted from the } \\
\text { patient-generated } \\
\text { journal }\end{array}$ & $\begin{array}{l}\text { Information from } 56 \\
\text { clinically stable adult } \\
\text { patients }(>18 \text { years of } \\
\text { age) receiving care at } \\
\text { the ED at HRH from } \\
\text { January-May } 2019\end{array}$ & $\begin{array}{l}\text { - Gender: } 54 \% \text { females, } 46 \% \text { males } \\
\text { - } \quad \text { Age: range from } 18-79 \text { years, mean age } 46.6 \text { years } \\
\text { Patient type: } 70 \% \text { medical patients, } 30 \% \text { surgical patients }\end{array}$ \\
\hline 3 & $\begin{array}{l}\text { Self-completion } \\
\text { questionnaire }\end{array}$ & $\begin{array}{l}\text { - } 9 \text { physicians working } \\
\text { at the ED at HRH, } \\
\text { that had used the PGJ } \\
\text { to some degree in the } \\
\text { ED at HRH. }\end{array}$ & $\begin{array}{l}\text { - Gender: } 6 / 9(67 \%) \text { females, } 3 / 9(33 \%) \text { males } \\
\text { - } \quad \text { Age: Range from } 20-40 \text { years, } 8 / 9(89 \%) \text { in the age group } 20-30 \text { years } \\
\text { - Years of experience in the field of emergency medicine: } 9 / 9(100 \%) 0-1 \text { year } \\
\text { - } \text { ( } 11 \% \text { ears of experience as a trained physician: } 6 / 9(67 \%) 0-1 \text { year, } 2 / 9(22 \%) 2-4 \text { years, } 1 / 9 \\
\text { - To what extent tested the PGJ concept: } 7 / 9(78 \%) 1-4 \text { patients, } 2 / 9(22 \%) 5-9 \text { patients }\end{array}$ \\
\hline 4 & $\begin{array}{l}\text { Qualitative } \\
\text { interviews }\end{array}$ & $\begin{array}{l}\text { - } 3 \text { healthcare leaders } \\
\text { from the ED at HRH }\end{array}$ & - One consultant and two nurses that had leader functions within the department \\
\hline
\end{tabular}

Tabel 1: Description of data 
issues were observed in the statistical data extracted from the PGJ which showed that, on average, patients spent 36.7 minutes (SD 13.8) filling in the data, including disturbances occurring during data entry (Table 2). Lastly, the patients were asked if they would have been able to fill in the PGJ at home before arriving at the ED. Slightly more than half agreed to this $(66.7 \%$; Figure 1) , but the majority stated that they would prefer to do it at the ED due to lack of time and the need for support during data entry.

The physicians expressed mixed experiences and attitudes towards the PGJ. Slightly more than half agreed that the system helped by giving an improved overview of a patient's symptoms, that it was more time-efficient compared to conventional methods, and that patients appeared more prepared and active in the consultation when using the PGJ. However, most physicians agreed that the system needed improvements to gain these benefits. Their arguments indicated a strong need for integration between the PGJ and the existing electronic health record (EHR) to facilitate improved documentation and workflow. They also stated that they often needed to wait for patients to finish their data entry due to the length of the PGJ, which could lead to delays in patient care. All physicians ended the survey agreeing that the PGJ has the potential to be valuable within emergency medicine in the future when further developed and adjusted to the clinic. See Appendix 2 for examples of citations from the questionnaire.

The leaders at the ED had a positive attitude towards the PGJ, with an expectation of enhanced efficiency in the department when implementing the system. They further identified two main barriers for Patients' attitude towards the PGJ

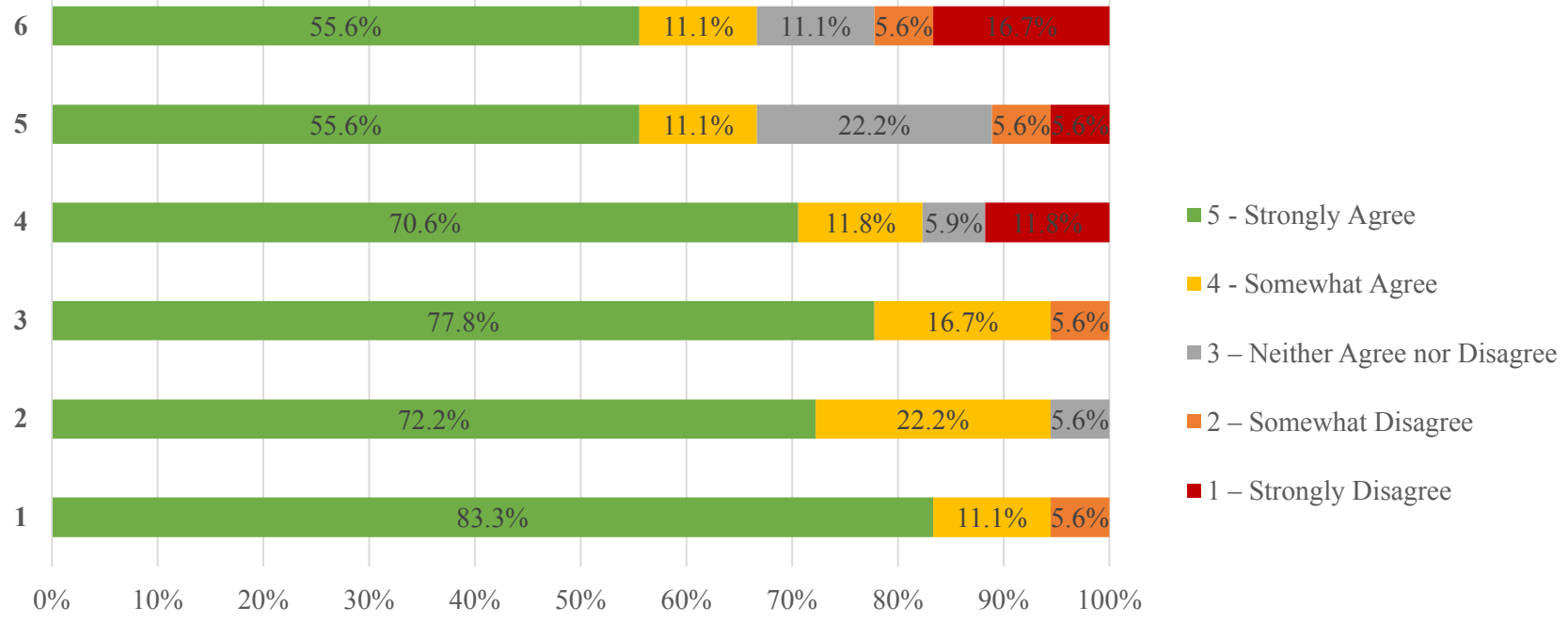

Rated statements:

1: I understand why I should contribute by providing information to the physician. I can therefore see the meaning in contributing with information about my health.

2: I find the patient-generated journal easy to use.

3: I find the utilisation of the waiting time valuable, as I can contribute by providing information to the physician.

4: It gives me comfort knowing that I have actively contributed with information regarding my health and that I can make use of this information in the dialouge with the physician when he/she is assessing me.

5: I have an improved overview of my condition and a greater understanding of the patient pathway when using the patient-generated journal.

6: I would be able to register the information about my health from home using the application if this was an option. The time before arriving at the emergency clinic would be better utilised if this was possible. 


\begin{tabular}{|c|c|c|c|c|c|c|}
\hline Variable & Mean & Median & Min & Max & Range & SD \\
\hline $\begin{array}{l}\text { Total number of } \\
\text { symptoms reported }\end{array}$ & 25.77 & 26 & 7 & 47 & 40 & 9.47 \\
\hline $\begin{array}{l}\text { Recently occurred } \\
\text { symptoms } \\
\text { (experienced the last } \\
3 \text { months) }\end{array}$ & 9.27 & 9 & 1 & 24 & 23 & 6.08 \\
\hline Time & $36.7 \mathrm{~min}$ & $33.7 \mathrm{~min}$ & $7.1 \mathrm{~min}$ & $73.7 \mathrm{~min}$ & $66.6 \mathrm{~min}$ & $13.8 \mathrm{~min}$ \\
\hline
\end{tabular}

Tabel 2: Statistical overview of data extracted from the PGJ (The number of symptoms may be slightly overestimated due to the inclusion of reported exposures and double reporting of symptoms for validation purposes)

implementation: the need for integration between the

PGJ and EHR system, and the change in tasks and interprofessional collaboration needed when implementing a PGJ in an urgent setting. See Appendix 3 for examples of citations from the interviews.

\section{Discussion}

The results support that patients in urgent settings who are clinically stable are willing and able to be active and involved in their care by reporting information about their health in the PGJ. The majority of patients were positive about the PGJ and found it beneficial to both them and the physicians, but thought that it needed improvements to fit their capacity in the urgent situation. International studies conducted in EDs have shown similar findings; that is, that the use of a digital device is well accepted by patients in urgent settings, and computer interviews could improve patient pathways in EDs if adjusted to patient abilities $(3,8)$.

Both physicians and leaders had mixed perceptions of the PGJ. The majority agreed that it had the potential to be a valuable tool, but that it would need to be integrated with the EHR system and further developed before being beneficial. Similar challenges have been identified in previous studies, which stated that integration was essential for computer-based interviews to benefit both patients and clinicians (9).

All data used in this study were collected at one ED by the same investigators, which improves the internal validity of the data. The mixed-method approach, where both quantitative and qualitative data were collected simultaneously, made it possible to expand on findings and allowed for validation of data between methods. This also strengthens the credibility and internal validity of the study.

Fieldwork - Patients

Data saturation was achieved for the fieldwork. The patients were purposely chosen for their variance in age, gender, triage level and patient type, to avoid a homogenous data sample. These choices strengthen the internal and external validity of the data.

Questionnaire - Physicians

The physicians represented a homogeneous group due to similarities in characteristics (Table 1). This has not been valued negatively as this group of physicians is normally represented in an ED. However, only a small number of physicians were able to test the concept on a limited number of patients, which weakens the internal and external validity. 
Even though the study supports the concept of utilising patient-reported health data in emergency care, the results cannot be generalised due to the size and composition of the sample. Future studies should systematically select a specific and larger sample, to enable more generalisable results.

Despite these limitations, this study shows that the use of a PGJ in an ED has great potential, but further development and investigation is needed to ensure a valuable and financially viable solution.

\section{Conclusion}

Based on this study it can be argued that a fully integrated PGJ may help provide more efficient and effective delivery of care in EDs in Denmark through standardised sharing of data and promotion of patient involvement. This study supports that using patient-generated data is well accepted by stable patients in an urgent setting and that the PGJ has the potential to improve quality in patient pathways by adding value to patient flows as well as clinical workflows.

\section{Acknowledgements}

We thank the Innovation Department at New Hospital North Zealand, the primary host of BSS's and FBK's thesis project, for their support in the development of the data-collection methods used in this study. We also thank the Innovation Department, $\mathrm{HRH}$, for their administrative support, the staff at the $\mathrm{ED}, \mathrm{HRH}$, for their practical help throughout the data collection, and Nad Husainov (NH), IT specialist, for technical support of the PGJ.

\section{Disclosure}

PGJ V.1.0 was developed by $\mathrm{MK}$ and $\mathrm{NH}$ prior to the initiation of this study. No commercial funding or other form of financial support was received. Additionally, none of the developers was responsible for the data collection or analysis performed. 


\section{References}

1. Swancutt D, Joel-Edgar S, Allen M, Thomas D, Brant $\mathrm{H}$, Benger $\mathrm{J}$, et al. Not all waits are equal: an exploratory investigation of emergency care patient pathways. BMC Health Serv Res. 2017;17(1): 436. https://doi.org/10.1186/s12913-017-2349-2

2. Danske Regioner, Sundhedsstyrelsen og Sundheds- og ÆEldreministeriet. DE DANSKE AKUTMODTAGELSER - STATUS 2016 [Internet]. 2016. Available from: https://sum.dk/Aktuelt/Publikationer/De-danskakutmodtagelser-maj-2016.aspx [Access date 1 Feb 2020]

3. Benaroia M, Elinson R, Zarnke K. Patient-directed intelligent and interactive computer medical historygathering systems: a utility and feasibility study in the emergency department. Int $\mathrm{J}$ Med Inform. 2007;76(4):283-8.

https://doi.org/10.1016/j.ijmedinf.2006.01.006

4. Bachman JW. The patient-computer interview: a neglected tool that can aid the clinician. Mayo Clin Proc. 2003;78(1):67-78. https://doi.org/http://dx.doi.org/10.4065/78.1.67

5. Bachman J. Improving care with an automated patient history. Fam Pract Manag. [Internet]. 2007;14(7):39-43. Available from: https://www.ncbi.nlm.nih.gov/pubmed/17696057 [Access date 5 Jan 2020]
6. Slack WV, Kowaloff HB, Davis RB, Delbanco T, Locke SE, Bleich HL. Test-retest reliability in a computer-based medical history. J Am Med Inform Assoc. 2011;18(1):73-6. https://doi.org/10.1136/jamia.2010.005983

7. Slack WV, Kowaloff HB, Davis RB, Delbanco T, Locke SE, Safran C, et al. Evaluation of computerbased medical histories taken by patients at home. J Am Med Inform Assoc. 2012;19(4):545-8. https://doi.org/10.1136/amiajnl-2011-000580

8. Herrick DB, Lehmann HP, Nakhasi A, Abbott PA, Tehrani ASS, Newman-Toker DE, et al. Usability characteristics of self-administered computerassisted interviewing in the emergency department. Appl Clin Inform. 2013;04(02):276-92. https://doi.org/10.4338/ACl-2012-09-RA-0034

9. Moore BJ, Gaehde S, Curtic C. Architectural choices and challenges of integrating electronic patient questionnaires into the electronic medical record to support patient-centered care. AMIA Annu Symp Proc. [Internet]. 2008;2008:490-4. Available from:

https://www.ncbi.nlm.nih.gov/pmc/articles/PMC265 5980/ [Access date 5 Jan 2020] 


\section{Subjektiv Journal}

\section{Patient}

Demo Patient [1234567890]

35-årig kvinde modtages via egen læge, som akut indlagt patient

(Axigram sagsnr. 43; patienten vurderet som habil for PGJ)

\section{Allergi}

For: Græs

\section{Dispositioner}

Ingen kendte medfødte, sukkersyge, blodpropper, arvelige, kræft eller fælles sygdomme i familien

\section{Expositioner}

- har haft rejser i de sidste 3 mndr.

- har kontakt med dyr

\section{Tidligere}

Tidligere sygdomme:

- Forkølelse

Tidligere operationer:

- 2017 feb., Bryst

\section{Medicin}

Ingen

Tobak
Ryger ikke

\section{Alkohol}

Drikker: under 7 genstande / uge

\section{Social}

Bor ikke alene. Har pårørende. Arbejder (Kontor).

\section{Aktuel}

Patientens starste Kager:

hævelse (venstre underarm forfra)

2. konstant nedsat hørelse

3. konstant muskelsmerter

Andre aktuelle symptomer:

- ændret følesans (venstre side af brystet , venstre overarm forfra, venstre underarm forfra, venstre skulderområde forfra)

- kroniske smerter (venstre side af brystet, venstre skulderområde forfra)

Systematisk adspurgt og nævner følgende symptomer

- intermitterende øresmerter

- tinnitus

- intermitterende balanceproblemer

- konstant tæt i næsen

Kroniske (mere end 3 måneder):

konstant tab af lugtesans

- konstant nakkesmerter

- konstant skuldersmerter

- intermitterende svedeture

- konstant følelsesændringer på kroppen

- konstant udstråling af smerter

- intermitterende nedsat immunitet

\section{Symptom-tidslinje}

(beta)

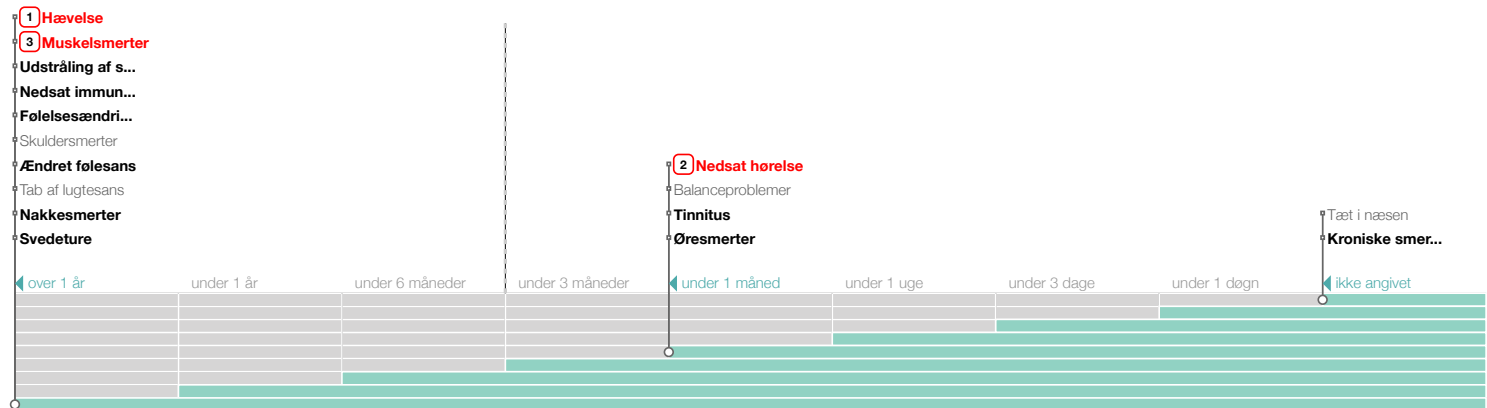




\section{Appendix 2: A few selected citations from the open-ended questions in the physicians' self-completion questionnaire}

It is great that it differentiates between the main symptoms and other symptoms. And the timeline makes it easy to distinguish between new and old symptoms, which might otherwise be difficult when you talk with the patient.

Regarding disease history, it is my experience that in fact, very few patients are fully aware of what they have previously been operated for or have been hospitalized with. There are also many patients who are not particularly well-informed in their medicine. Would it be possible to integrate the PGJ with FMK (the medicine part of the EHR system) and extract data, which patients should then tick and accept or decline?

If the patients are thoroughly instructed in the use of the iPad, and the responses will enter automatically into the EHR system, it will clearly facilitate an improved documentation and workflow.

\section{Appendix 3: A few selected citations from the qualitative interviews with the health care leaders}

The expectation for this is firstly, that is quite obvious, that the patients feels more involved and can communicate their information in a quick and efficient way. The experienced gaps where the patient does not know what is going on behind the scenes, there they now actually have something to do, then they feel involved in it.

I believe that the most important thing for the viability is the integration with our existing system.

I believe that we need to be the first to see the meaning in it, to motivate our nurses. There are not any of us who don't believe it is a good idea, and we would like to help with it. But it's really about seeing the multidisciplinary purpose in it, I think. 